\title{
Karakter ve değerler eğitimi dersinin Türk dili ve edebiyatı öğretmeni adaylarının değer eğitimine yönelik tutumları üzerindeki etkisinin incelenmesi
}

\section{Nurullah SAHİN 1}

\begin{abstract}
APA: Şahin, N. (2019). Karakter ve değerler eğitimi dersinin Türk dili ve edebiyatı öğretmeni adaylarının değer eğitimine yönelik tutumları üzerindeki etkisinin incelenmesi. RumeliDE Dil ve Edebiyat Araştırmaları Dergisi, (15), 63-78. DOI: 10.29000/rumelide.580457
\end{abstract}

$\ddot{\mathbf{O} z}$

Bu araştırmanın amacı; Karakter ve Değerler Eğitimi dersinin, öğretmen adaylarının değer eğitimine yönelik tutumları üzerindeki etkisini tespit etmektir. Çalışmada nicel araştırma yaklaşımı benimsenmiş olup yöntem olarak tek grup ön test - son test basit deneysel desen kullanılmıştır. Araştırmanın çalışma grubunu 2018-2019 eğitim öğretim yılı güz yarıyılında, Sinop Üniversitesi Pedagojik Formasyon Programı'nda, seçmeli ders olarak Karakter ve Değerler Eğitimi dersini seçen 50 Türk dili ve edebiyatı öğretmeni adayı oluşturmaktadır. Araştırmada veri toplama aracı olarak Çetin (2018) tarafından geliştirilen “Değer eğitimine yönelik tutum ölçeği” kullanılmıştır. Deneysel işlemlerin öncesinde ön test, sonrasında ise son test olarak çalışma grubuna uygulanan ölçek, 3 alt boyut ve 31 maddeden oluşmaktadır. Araştırmadan elde edilen tüm veriler SPSS 25 paket programında analiz edilmiştir. Öğretmen adaylarının ön test ve son test puanları arasındaki farkın anlamlı olup olmadığını tespit etmek için bağımlı değişken t- testi analizi kullanılmıştır. Uygulamaları toplamda 14 hafta süren araştırmanın sonunda Karakter ve Değerler Eğitimi dersinin, öğretmen adaylarının değer eğitimin gerekliliğine olan inanç ve değer eğitimini içselleştirme alt boyutlarına yönelik tutumlarını artırdı̆̆ı görülmüştür. Ölçeğin bir diğer alt boyutu olan değer eğitimine yönelik olumsuz inanç boyutunda ise, öğretmen adaylarının ön test ve son test puanları arasında anlamlı bir fark olmadı̆̆ı, öğretmen adaylarının deneysel işlemler öncesinde değer eğitimine yönelik olumsuz inançları olmadığı gibi deneysel işlemler sonrasında da öğretmen adaylarında değer eğitimine yönelik olumsuz bir inanç gelişmediği görülmüştür.

Anahtar kelimeler: Karakter ve Değerler Eğitimi dersi, değer eğitimine yönelik tutum, öğretmen adayları.

\section{Examination of the impact of the course of character and value education on the attitudes of Turkish language and literature prospective teachers about value education}

\begin{abstract}
The purpose of this survey is to determine the impact of the course of Character and Value Education on the attitudes of prospective teachers about value education. The quantitative research approach has been adopted in this study and the pattern of single group preliminary test- final test was used as a method. The study group of this research study is formed by 50 Turkish language and literature prospective teachers who have selected the course of Character and Value Education as the elective course in the Pedagogical Formation Program of Sinop University in the fall semester of the academic year 2018-2019. "Attitude scale on value education" developed by Cetin (2018) has been used as a
\end{abstract}

1 Dr. Öğr. Üyesi, Ağrı İbrahim Çeçen Üniversitesi, Eğitim Fakültesi, Türkçe ve Sosyal Bilimler Eğitimi Bölümü, (Ağrı, Türkiye), nsahin.86@gmail.com, ORCID ID: 000o-0002-3462-0369 [Makale kayıt tarihi: 14.05.2019-kabul tarihi: 15.06.2019; DOI: 10.29000/rumelide.580457] 
Examination of the impact of the course of character and value education on the attitudes of Turkish language and literature prospective teachers about value education / N. Şahin (p. 63-78)

\begin{abstract}
means of data collection in the survey. The scale which was used as a preliminary test prior to the experimental processes and as a final test thereafter on the study group consists of 3 sub-dimensions and 31 articles. All data obtained from the survey were analyzed in SPSS 25 package program. The dependent variable t-test was used to determine whether the difference between the preliminary and final test scores are meaningful. At the end of the survey the applications of which lasted 14 weeks, it was observed that the course of Character and Value Education has increased the attitudes of the prospective teachers directed at the sub-dimensions of the belief in the necessity of value education and internalization of value education. On the other hand, in the dimension of the negative belief on the value education which is another sub-dimension of the scale it has been observed that there is no meaningful difference between the preliminary and final test scores of the prospective teachers, that the prospective teachers had no negative opinion about the value education prior to the experimental processes, nor such a negative opinion has emerged after the experimental processes.
\end{abstract}

Keywords: Course of character and values, attitude about value education, prospective teacher.

\title{
Giriş
}

Değer kavramı, günümüz dünyasında üzerinde en çok konuşulan konulardan biri olarak karşımıza çıkmaktadır. Günümüz toplumlarının başta ahlak olmak üzere inanç, tarih, maneviyat, millî bilinç $v b$. alanlarda yaşadığı çöküş; değer konusunun yeniden gündeme gelmesi ve üzerinde çokça düşünülmesi zorunluluğunu da beraberinde getirmiştir. Bu sebeple değer kavramı; birçok bilim dalının inceleme alanına girmiş ve her bilim dalında değerlerle ilgili çeşitli araştırmalar yapılmıştır, yapılmaktadır. Özgüven, bu duruma şöyle değinmektedir: "Değerler, uzun yıllardır sosyolojiden felsefeye, antropolojiden psikolojiye kadar birçok alanın çalışma konusu olmuştur. Son ylllarda da eğitimin öncelikli konuları arasında yer almaktadır" (Özgüven, 1994, s. 349). Başta sosyoloji, psikoloji, felsefe, tarih, eğitim bilimleri olmak üzere birçok bilim dalının araştırma alanına giren değer kavramına yönelik her bilim dalı kendi perspektifinden bakarak çeşitli açıklamalar ve tanımlar getirmişlerdir.

Değer kavramı hakkında farklı bilim alanlarından bilim adamlarınca yapılmış birçok tanım olmasına rağmen üzerinde fikir birliğine varılmış bir tanımdan bahsetmek mümkün değildir. Değer kavramına ilişkin tanımların tamamını burada sıralamak mümkün olmasa da bunlardan bazılarını vermek faydalı olacaktır. Türk Dil Kurumunun yapmış olduğu tanıma bakılacak olursa;

"Bir şeyin önemini belirlemeye yarayan soyut ölçü, bir şeyin değdiği karşılık, kıymet. Bir ulusun sahip olduğu sosyal, kültürel, ekonomik ve bilimsel değerlerini kapsayan maddi ve manevi ögelerin bütünü” (TDK, 2015) şeklinde bir tanım görülmektedir.

Bilgin ise değer kavramı ile ilgili "genelde inanılan, arzu edilen ve davranışlar için bir ölçek olarak kullanılan olgulardır. İlk defa Znaniecki tarafından sosyal bilimlere kazandırılan değer kavramı Latince kıymetli olmak veya güçlü olmak anlamlarına gelen valere kökünden türetilmiştir" $(1995$, s. 83) ifadelerini kullanmıştır.

Halstead ve Taylor ise, değer kavramına birey açısından bakarak değer kavramının kişilerin davranışları üzerindeki etkisine dikkat çekmiş ve değeri "davranışlara genel olarak rehberlik eden ilkeler ve temel inançlar, eylemlerin iyi ya da istenilen olarak yargılandığı standartlar” şeklinde tanımlanmışlardır (2000, s. 169).

Değerlerin, bireyin davranışları üzerindeki etkisine dikkat çeken bir başka isim ise, Beil'dir. Ona göre; 
Değerler, bireylerin kendileri ve başkalarıyla ilgili davranışlarına yön verip, davranış kılavuzu görevi yapmaktadır. Her birey kendisi için önemli sayılan değerler için çaba sarf etme olanağına sahiptir. Herkes sosyal çevresinde hangi davranışı daha geçerli olduğuna hangisinin geçersiz olduğuna ilişkin önceden belirlenmiş yerleşmiş değer yargıları ile karşılaşır. Bireyler toplumsal kurallar, gelenek ve görenekler yoluyla "iyi" ve "kötüyü", "doğru” ve "yanlışı" ayırt ederek kendi ahlak ilkeleri doğrultusunda bir ölçü edinmeyi öğrenirler (Beil, 20o3, s. 13-14).

Değer kavramına toplum açısından bakarak yola çıkan bilim adamlarının yaptıkları tanımlara bakılacak olursa;

Alylmaz ve Alyllmaz, değerlerin toplumun bireylerini bir araya getirici ve bir arada tutucu özelliğinden bahsederek "Toplumların oluşumunda ve birlikteliklerinde ortak değerlerin rolü büyüktür. Ortak değerler, ortak yaşayış ve inanışın, amaç ve ihtiyaçların ürünüdür” (2014, s. 77) ifadelerini kullanmışlardır. Konunun biraz daha detaylarına değinen Cengiz Alyılmaz, aşağıdaki açıklamalara yer verir:

Sistemler üstü bir sistem ve mükemmel bir varlık olarak yaratılmışhğın bilincinde olan insanoğlunun iyi, güzel, doğru, mutlu ve huzurlu bir yaşam sürmesi bir anlamda içinde yaşadiğı toplumla ilgilidir. Nitekim insanı temel, toplumsal ve evrensel değerlerle bütünleştirip bireysel ve toplumsal huzura kavuşturacak, aym zamanda seçkin ve aydın kılacak etmenlerin başında içinde yaşadığı toplumun değerleri / değer yargıları gelir (2008, s. 137).

Aynı bakış açısıyla konuya yaklaşan Dökmen ise, "Kişilerin bir arada yaşayabilmeleri için birtakım değerlere sahip olmaları gerekir. Birey, sahip olduğu değerler sayesinde sosyal yaşamını biçimlendirir, diğer insanlar arasında varlığını gösterebilir. Kendinde bulunan değerler aracılığıyla, bulunduğu toplumdaki veya gruptaki diğer bireylerin davranışlarını yorumlayabilir veya tahmin edebilir" (2000, s. 3) görüşündedir.

\section{Değer eğitimin önemi}

Ana hatları ile bakıldığında, bireyi içinde yaşadığı toplumun istediği yönde yetiştirme ve kültürleme işi olarak ifade edilen eğitim; aynı zamanda toplumun kültürünü ve varlığını devam ettirmesinin de en önemli yoludur. Literatür incelendiğinde, bu durumun bilim adamlarınca ifade edildiği görülmektedir.

Gelişim aşamalarma göre farkh seviyeler olan toplumlar kendilerine özgü bir anlayışla insan yetiştirmeye çalışmaktadırlar. Bu süreçte, toplumsal anlayışa uygun bireyler yetiştirmek için kullanulacak en temel kurum eğitimdir. Eğitime yön veren ise kültürdür. Her toplum kendi özünü, kültürünü koruyarak varhğını devam ettirme isteğinde olduğundan, bu özün korunmasında eğitim öne çıkmaktadir. (Akyüz, 1991, s. 157).

Aynı durum, Erdentuğ tarafından ise, şu ifadelerle dile getirilmiştir:

Bir insanı içinde yaşadığı toplumun ve kültürün bir üyesi hâline getiren süreç "ham insan tabiatının yoğrulması”dır. Bu yoğrulma işi, öğrenme arachlğ̆yla gerçekleşir. Başka bir ifadeyle eğitim, insanın öğrenme yolu ile sonradan kazanmış olduğu birtakım davranışlartn dâhil olduğu bir yoğrulma işidir. Bunda kültürün büyük payı vardır. Çünkü öğrenimin çoğu ilgili toplum tarafindan tayin ve kontrol edilir (Erdentuğ, 1982, s. 373).

Günümüz dünyasında yaşayan toplumların en büyük sorunlarından biri de varllğını ve kültürünü geleceğe taşıma meselesidir. Güçlü bir eğitim sistemine ve anlayışına sahip toplumlar bu bağlamda kahıcı ve etkili çözümler üretebilirken, eğitim bakımından geri kalmış toplumlar yavaş yavaş başka toplumların ve medeniyetlerin altında asimile olmaya yüz tutmuşlardır. Çünkü kendi kültürel ve değer genlerine uygun bireyler yetiştiremeyen toplumlar ve sahip oldukları kültürel birikim, gelecekte kendine yer 
Examination of the impact of the course of character and value education on the attitudes of Turkish language and literature prospective teachers about value education / N. Şahin (p. 63-78)

bulamayacaktır. Bulsa da başka ulusların egemenliği altında silik ve etkisiz bir yaşama mahkûm kalacaktır. Bununla ilgili Bayram ve Yılmaz, şu ifadelere yer vermektedir:

Toplumlarm değişen zaman içinde varlkkların sürdürebilmeleri için ortak duyuş, düşünüş, kültür ve değerlerin diğer nesillere aktarımı gerekmektedir. Bu aktarım söz konusu toplumsal yaşam içinde ilk sosyal yapı olan aile, yakın ve uzak çevre ve nihayetinde planl, programl bir şekilde okullarda gerçekleşir (2019, s. 283).

Kısaca; kendi kültür ve değerlerini genç nesillerine aktarmayı başaran toplumlar ancak kendi bekalarını teminat altına alabileceklerdir. Bu durum Er (2017) tarafından şu şekilde ifade edilmiştir: "Aynı zamanda kültürden kaynaklı değişim ve ilerleme toplumu da etkiler. İnsanlar çok zengin olabilirler, çok dil bilebilirler, çok çeşitli kültürleri görebilirler; ancak onlar kendi değerlerini korudukça ve gelecek kuşaklara taşıdıkça var olabilirler. Çağdaşlıkta bunu gerektirmektedir” (Er, 2017, s. 1179).

Tüm bu sebeplerle değer eğitimi toplumların geleceğini doğrudan etkileyen önemli bir mesele olarak karşımıza çıkmaktadır.

Konuyla ilgili olarak Doğan, "Bir ülkenin eğitim sistemi o ülkenin önem verdiği ve eğitim sistemine de yansımış olan değerlerle başlar. Bu değerler eğitimin çerçevesini, amaçlarını ve yönünü belirler” (Doğan, 1997, s. 18) değerlendirmesini yapmaktadır. Kültürün ve değerlerin geleceğe taşınmasının önemi hakkında Köktürk ise şu değerlendirmelerde bulunmaktadır:

Din, hukuk, devlet, ahlak, bilim, dil edebiyat, sanat, ekonomi ve teknik vasitalar kültür objeleridir ve nakledilebilir mülkiyetlerdir. Kültür olgusu olmanın kıstası, onlara sinmiş olan değerlerin toplumun üyeleri tarafindan geçerli kabul edilmesidir. Bu geçerlilik talebi ve gereği toplumun sonraki kuşaklarını da kapsar. Dolayısıyla yansıyan ya da nakledilen şey, aslında 'değerler'dir (Köktürk, 2006, s. 274).

Konuyla ilgili olarak Kavcar’ın çağdaş eğitimin amacını da ifade ettiği görüşleri şöyledir:

En geniş ve genel anlamıyla eğitim, çocuk olsun, genç olsun, yaşh olsun, insanlarda sosyal hayata ve çağa uygun tutum ve davranış değişikliği sağlamaktır. Ĕ̆itimin işlevi topluma sağlikh bir biçimde uyum yapabilmeleri için insanları etkilemektir. Bu etkileme, geçmişteki sosyal ve ulusal değerleri tanıtıp benimsetme, bugünün gerçeklerini gösterme ve geleceğe dönük değerler, hünerler kazandırma yoluyla olur. Çağdaş eğitimin amacı, dünü koruyarak yarın güven altına almaktır... Kısacası eğitimden beklenen üç esas; dünü tanttma, bugünü kavratma ve yartna hazırlamadır (Kavcar, 1999, s. 1).

Yukarıda ifade edilenler göstermektedir ki; değer eğitimi hayati önem arz etmektedir. Böyle bir düzlemde eğitimcilere önemli sorumluluklar düşmektedir.

Eğitimin birincil amaçları arasında yer alan kültürü ve değer yargılarımı bir sonraki nesle aktarma işi, öncelikle hangi değerlerin aktarlacağının, bu değerlerin nasıl aktarlacağının, bu süreçte eğitimcilerin sahip olması gereken niteliklerin ve davranışların nasıl olması gerektiğinin tespit edilmesiyle yakından ilgilidir. Bu nedenle să̆hkl bir değer öğretimi programına ve sürecine ihtiyaç vardır (Şahin, 2017, s. 60).

Günümüzde değer eğitiminin önem kazanmasının sebeplerinden biri de, çağdaş insanın içine düştüğü çıkmazlardır. İnsanların günümüzde değerlerden kopuk ve amaçsız bir hayat sürmesi, içinde yaşadığımız dünyayı da cehenneme çevirmektedir. Bu perspektiften bakıldığında Kale (2004, s. 319), değerler eğitiminin amacını şöyle ifade etmektedir:

Bireyleri evrensel (etik) ve kültürel değerlere ve bunlarm önemine ilişkin bilinçlendirmek, demokratik tutumlarla, hoşgörüyle çok kültürlülüğü ilişkilendirmek, naturalist bir hümanizmi vurgulamak, tüm değerleri insanın varlk şartları ve olanakların geliştirme ölçütüyle 
değerlendirmek, etik değerlere ilişkin somut problemlerden hareketle hayatı bilgiye ve / veya bilgiyi hayata dönüştürmek.

Bütün bu nedenlerden sonra açlk bir şekilde ifade edilebilir ki; değerler eğitimi, "eğitimin her kademesinde yer almalı ve buna yönelik son derece hassas bir şekilde oluşturulmuş öğretim programları ve eğitim süreçleri hazırlanmalıdır” (Şahin, 2017, s. 61).

\section{Araştırmanın amacı}

Bu çalışmada, Karakter ve Değerler Eğitimi dersinin öğretmen adaylarının değer eğitimine yönelik tutumları üzerindeki etkisini tespit etmek amaçlanmıştır. Bu amaç doğrultusunda çalışmanın alt problemleri aşağıdaki şekilde belirlenmiştir:

1. Karakter ve Değerler Ĕ̆itimi dersini alan öğretmen adaylarının, değer eğitiminin gereğine olan inanç bağlamında almış oldukları ön test ve son test puanları arasında anlamlı bir fark var midir?

2. Karakter ve Değerler Eğitimi dersini alan öğretmen adaylarının, değer eğitimini içselleştirme bağlamında almış oldukları ön test ve son test puanları arasında anlamlı bir fark var mıdır?

3. Karakter ve Değerler Eğitimi dersini alan öğretmen adaylarının, değer eğitimine yönelik olumsuz inanç bağlamında almış oldukları ön test ve son test puanları arasında anlamlı bir fark var midır?

\section{Yöntem}

\section{Çalıșmanın deseni}

Karakter ve Değerler Eğitimi dersinin, öğretmen adaylarının değer eğitimine yönelik tutumlarının üzerindeki etkilerinin araştırıldığı bu çalışmada, nicel araştırma yaklaşımlarından tek grup ön test son test basit deneysel desen kullanılmıştır. Bu desende, tek bir gruba bağımsız değişken uygulanır ve deneklerin ölçümleri uygulama öncesinde ön test, sonrasında ise son test olarak gerçekleştirilir. Aynı denekler üzerinde aynı ölçme araçları kullanılarak elde edilen ön test son test ortalamaları arasındaki fark bağımsız değişkenin bağımlı değişken üzerindeki etkisini gösterir. (Büyüköztürk, 2007; Karasar, 2003; Cohen ve Manion, 1997; Gay ve Airasian, 2000; Fraenkel ve Wallen, 1996; Nachmias ve Nachmias, 1997).

\section{Çalışma grubu}

Çalışma, 2018-2019 eğitim öğretim yılı güz dönemi içerisinde Sinop Üniversitesi Pedagojik Formasyon Programı'nda öğrenim görmekte olan ve seçmeli ders olarak Karakter ve Değerler Eğitimi dersini seçen 50 Türk dili ve edebiyatı öğretmeni adayı ile gerçekleştirilmiştir. Öğretmen adaylarının cinsiyet değişkenine göre dağılımı Tablo 1'de verilmiştir.

Tablo 1. Çalışma Grubunun Cinsiyet Değişkenine Göre Dağılımları

\begin{tabular}{ccc}
\hline Cinsiyet & f & $\%$ \\
\hline Kadın & 30 & 60 \\
\hline Erkek & 20 & 40 \\
\hline Toplam & 50 & 100 \\
\hline
\end{tabular}


Examination of the impact of the course of character and value education on the attitudes of Turkish language and literature prospective teachers about value education / N. Şahin (p. 63-78)

\section{Verilerin toplama araçları}

Araştırmada veri toplama aracı olarak Çetin tarafından geliştirilen ve 2018 yılında yayınlanan "Değer Eğitimine Yönelik Tutum Ölçeği” kullanılmıştır. İlgili ölçek araştırmanın başında deneklere ön test, sonunda ise son test olarak uygulanmıştır. Aşağıda ölçek ile ilgili detaylı bilgilere yer verilmiştir.

Çetin, ölçeği geliştirirken ilk olarak ilgili literatürü tarayarak ölçek maddeleri oluşturmuş ve bu maddelerin kapsam ve görünüş geçerliliklerini belirlemek amacıyla alanda uzman akademisyenlerin görüşüne başvurmuştur. Akademisyenlerden alınan görüşler doğrultusunda 43 maddelik bir ön deneme formu oluşturan Çetin, bu formu Gazi Üniversitesi Eğitim Fakültesinde 2015-2016 eğitim öğretim yll güz döneminde öğrenim gören 200’ü kız 108’i erkek olmak üzere toplam 308 öğrenciye uygulamıştır. Uygulamalar sonucunda elde edilen veriler üzerinden yapı geçerliği için Açımlayıcı Faktör Analizi (AFA) ve Doğrulayıcı Faktör Analizi (DFA) uygulanmış ve üç faktörlü bir ölçek elde edilmiştir. Analizler sonucunda ölçeğin Cronbach Alfa iç tutarlılık katsayısı 0.95 (I. Alt faktör için .91, II. alt faktör için .87, III. Alt faktör için .71) olarak tespit edilirken, modele ilişkin değerler ise, RMSEA, .052; $\chi 2 / \mathrm{df}=1.6$; $\mathrm{NFI}=.94 ; \mathrm{NNFI}=.97 ; \mathrm{CFI}=.97 ; \mathrm{GFI}=.83 ; \mathrm{AGFI}=.81$ olarak belirlenmiştir. Çetin, çalışmasının sonunda, elde edilen değerlerin uyum indeksleri referanslarına dayalı olarak yeterli olduğunu, sonuç olarak değer eğitimine yönelik tutum ölçeğinin gerekli psikometrik özelliklere sahip bir ölçme aracı olduğunu ifade etmiştir.

\section{Uygulama süreci}

Bu çalışmada, Karakter ve Değerler Eğitimi dersinin, Türk dili ve edebiyatı öğretmeni adaylarının değer eğitimine yönelik tutumları üzerindeki etkisini tespit etmek amaçlanmıştır. Bu bağlamda araştırmanın uygulamaları 2018-2019 eğitim öğretim yılı güz yarıyılında, Sinop Üniversitesi Pedagojik Formasyon Programı'nda seçmeli ders olarak açılan Karakter ve Değerler Eğitimi dersinde gerçekleştirilmiştir. Araştırmanın uygulamaları toplamda 14 hafta sürmüştür. Derslerde Millî Eğitim Bakanlığı tarafından belirlenen kök değerler üzerinde durulmuştur. Bu değerler; adalet, dostluk, dürüstlük, öz denetim, sabır, saygı, sevgi, sorumluluk, vatanseverlik ve yardımseverliktir. Uygulama süreci; karakter ve değer eğitimi hakkında genel bilgilendirme (1 hafta), Değer Eğitimine Yönelik Tutum Ölçeği'nin ön test olarak öğrencilere uygulanması (1 hafta), adalet değerinin işlenmesi (1 hafta), dostluk değerinin işlenmesi (1 hafta), dürüstlük değerinin işlenmesi (1 hafta), öz denetim değerinin işlenmesi (1 hafta), sabır değerinin işlenmesi (1 hafta), saygı değerinin işlenmesi (1 hafta), sevgi değerinin işlenmesi (1 hafta), sorumluluk değerinin işlenmesi (1 hafta), vatanseverlik değerinin işlenmesi (1 hafta), yardımseverlik değerinin işlenmesi (1 hafta), genel bir değerlendirme yapılması (1 hafta) ve Değer Eğitimine Yönelik Tutum Ölçeği’nin son test olarak öğrencilere uygulanması (1 hafta) şeklinde ilerlemiştir.

Uygulama sürecindeki tüm dersler araştırmacı tarafindan yürütülmüştür. Uygulama sürecini ve derslerin içeriğini gösteren tablo aşağıda dikkatlere sunulmuştur. 
Tablo 2. Çalışmanın Uygulama Süreci

\begin{tabular}{|c|c|c|}
\hline Hafta & $\begin{array}{l}\text { Uygulama } \\
\text { Süreci }\end{array}$ & Ders İçeriği \\
\hline $\mathbf{1}$ & $\begin{array}{l}\text { Karakter ve } \\
\text { değer eğitimi ile } \\
\text { ilgili genel } \\
\text { bilgilendirme. }\end{array}$ & $\begin{array}{l}\text { Değer, karakter, değer eğitimi, karakter eğitimi, karakter ve değer eğitiminin } \\
\text { önemi, karakter ve değer eğitiminin tarihçesi konuları ile ilgili öğrencilerin ön } \\
\text { bilgilerini ortaya çıkarmak amacıyla sınıfa sorular soruldu. } \\
\text { Öğretmen yukarıdaki sıralanan konularla ilgili genel bilgileri düz anlatım } \\
\text { yöntemiyle anlattı. } \\
\text { Öğrencilerin soruları cevaplandı. }\end{array}$ \\
\hline 2 & $\begin{array}{l}\text { Değer Eğitimine } \\
\text { Yönelik Tutum } \\
\text { Ölçeği'nin ön test } \\
\text { olarak } \\
\text { ögrencilere } \\
\text { uygulanması }\end{array}$ & $\begin{array}{l}\text { Ölçek hakkında öğrencilere bilgi verildi. } \\
\text { Ölçeğin nasıl doldurulması gerektiği hakkında ö̆̆grencilere bilgi verildi. } \\
\text { Ölçek öğrencilere dağıtıldı ve öğrenciler ölçeği okuyup doldurduktan sonra } \\
\text { toplandı. }\end{array}$ \\
\hline 3 & $\begin{array}{l}\text { Adalet değerinin } \\
\text { işlenmesi }\end{array}$ & $\begin{array}{l}\text { Adalet değeri ile ilgili öğrencilerin ön bilgilerini ortaya çıkarmak için sorular } \\
\text { soruldu. } \\
\text { Adalet değeri ile ilgili bazı tanımlar ve bilgiler düz anlatım yöntemiyle anlatıldı. } \\
\text { Adalet değeri ile ilgili örnek olayların anlatıldı̆̆ı bazı videolar, fotoğraflar, } \\
\text { kıssalar, yaşanmış olaylar, hikâyeler ve adil olmalarıyla tanınmış önemli } \\
\text { şahsiyetler ögrencilerle paylaşıldı. } \\
\text { Adalet değeri ile ilgili atasözleri, vecizeler, deyimler, şiirler, şarkılar gibi bazı } \\
\text { ürünler öğrencilerle paylaşıldı. } \\
\text { Öğrencilerin, adalet değeri ile ilgili yaşadıkları anılarını paylaşmaları için } \\
\text { konuşmalarına fırsat verildi. } \\
\text { Beyin fırtınası yöntemi kullanılarak adaletin önemi, adaletin sınırları, adaletin } \\
\text { topluma ve bireye katkıları, adaletin olmadığı durumlarda nelerin yaşanabileceği } \\
\text { vb. konularda öğrencilerin görüşlerini paylaşmaları sağlandı. }\end{array}$ \\
\hline 4 & $\begin{array}{l}\text { Dostluk } \\
\text { değerinin } \\
\text { işlenmesi }\end{array}$ & $\begin{array}{l}\text { Dostluk değeri ile ilgili öğrencilerin ön bilgilerini ortaya çıkarmak için sorular } \\
\text { soruldu. } \\
\text { Dostluk değeri ile ilgili bazı tanımlar ve bilgiler düz anlatım yöntemiyle anlatıldı. } \\
\text { Dostluk değeri ile ilgili örnek olayların anlatıldı̆̆ı bazı videolar, fotoğraflar, } \\
\text { kıssalar, yaşanmış olaylar, hikâyeler ve dostluk değeri ile özdeşleşmiş önemli } \\
\text { şahsiyetler öğrencilerle paylaşıldı. } \\
\text { Dostluk değeri ile ilgili atasözleri, vecizeler, deyimler, şiirler, şarkılar gibi bazı } \\
\text { ürünler öğrencilerle paylaşıldı. } \\
\text { Öğrencilerin, dostluk değeri ile ilgili yaşadıkları anılarını paylaşmaları için } \\
\text { konuşmalarına fırsat verildi. } \\
\text { Beyin firtınası yöntemi kullanılarak dostluğun önemi, dostluğun sınırları, dostluk } \\
\text { değerinin topluma ve bireye katkıları, dostluk değerinin olmadığı durumlarda } \\
\text { nelerin yaşanabileceği vb. konularda öğrencilerin görüşlerini paylaşmaları } \\
\text { sağlandı. }\end{array}$ \\
\hline 5 & $\begin{array}{l}\text { Dürüstlük } \\
\text { değerinin } \\
\text { işlenmesi }\end{array}$ & $\begin{array}{l}\text { Dürüstlük değeri ile ilgili öğrencilerin ön bilgilerini ortaya çıkarmak için sorular } \\
\text { soruldu. } \\
\text { Dürüstlük değeri ile ilgili bazı tanımlar ve bilgiler düz anlatım yöntemiyle } \\
\text { anlatıldı. }\end{array}$ \\
\hline
\end{tabular}


Examination of the impact of the course of character and value education on the attitudes of Turkish language and literature prospective teachers about value education / N. Şahin (p. 63-78)

\begin{tabular}{|c|c|c|}
\hline & & $\begin{array}{l}\text { Dürüstlük değeri ile ilgili örnek olayların anlatıldı̆̆ı bazı videolar, fotoğraflar, } \\
\text { kıssalar, yaşanmış olaylar, hikâyeler ve dürüstlük değeri ile özdeşleşmiş önemli } \\
\text { şahsiyetler ögrencilerle paylaşıldı. } \\
\text { Dürüstlük değeri ile ilgili atasözleri, vecizeler, deyimler, şiirler, şarkılar gibi bazı } \\
\text { ürünler öğrencilerle paylaşıldı. } \\
\text { Öğrencilerin, dürüstlük değeri ile ilgili yaşadıkları anılarını paylaşmaları için } \\
\text { konuşmalarına fırsat verildi. } \\
\text { Beyin firtınası yöntemi kullanılarak dürüstlüğün önemi, dürüstlüğün sınırları, } \\
\text { dürüstlük değerinin topluma ve bireye katkıları, dürüstlük değerinin olmadığı } \\
\text { durumlarda nelerin yaşanabileceği vb. konularda öğrencilerin görüşlerini } \\
\text { paylaşmaları sağlandı. }\end{array}$ \\
\hline 6 & $\begin{array}{l}\text { Öz denetim } \\
\text { değerinin } \\
\text { işlenmesi }\end{array}$ & $\begin{array}{l}\text { Öz denetim değeri ile ilgili öğrencilerin ön bilgilerini ortaya çıkarmak için sorular } \\
\text { soruldu. } \\
\text { Öz denetim değeri ile ilgili bazı tanımlar ve bilgiler düz anlatım yöntemiyle } \\
\text { anlatıldı. } \\
\text { Öz denetim değeri ile ilgili örnek olayların anlatıldığı bazı videolar, fotoğraflar, } \\
\text { kıssalar, yaşanmış olaylar, hikâyeler ve öz denetim değeri ile özdeşleşmiş önemli } \\
\text { şahsiyetler öğrencilerle paylaşıldı. } \\
\text { Öz denetim değeri ile ilgili atasözleri, vecizeler, deyimler, şiirler, şarkılar gibi bazı } \\
\text { ürünler öğrencilerle paylaşıldı. } \\
\text { Öğrencilerin, öz denetim değeri ile ilgili yaşadıkları anılarını paylaşmaları için } \\
\text { konuşmalarına firsat verildi. } \\
\text { Beyin firtınası yöntemi kullanılarak öz denetimin önemi, öz denetimin sınırları, } \\
\text { öz denetim değerinin topluma ve bireye katkıları, öz denetimin olmadığı } \\
\text { durumlarda nelerin yaşanabileceği } v b \text {. konularda öğrencilerin görüşlerini } \\
\text { paylaşmaları sağlandı. }\end{array}$ \\
\hline 7 & $\begin{array}{l}\text { Sabır değerinin } \\
\text { işlenmesi }\end{array}$ & $\begin{array}{l}\text { Sabır değeri ile ilgili öğrencilerin ön bilgilerini ortaya çıkarmak için sorular } \\
\text { soruldu. } \\
\text { Sabır değeri ile ilgili bazı tanımlar ve bilgiler düz anlatım yöntemiyle anlatıldı. } \\
\text { Sabır değeri ile ilgili örnek olayların anlatıldı̆̆ı bazı videolar, fotoğraflar, kıssalar, } \\
\text { yaşanmış olaylar, hikâyeler ve sabır değeri ile özdeşleşmiş önemli şahsiyetler } \\
\text { öğrencilerle paylaşıldı. } \\
\text { Sabır değeri ile ilgili atasözleri, vecizeler, deyimler, şiirler, şarkılar gibi bazı } \\
\text { ürünler öğrencilerle paylaşıldı. } \\
\text { Öğrencilerin, sabır değeri ile ilgili yaşadıkları anılarını paylaşmaları için } \\
\text { konuşmalarına fırsat verildi. } \\
\text { Beyin fırtınası yöntemi kullanılarak sabrın önemi, sabrın sınırları, sabır değerinin } \\
\text { topluma ve bireye katkıları, sabır değerinin olmadığı durumlarda nelerin } \\
\text { yaşanabileceği vb. konularda öğrencilerin görüşlerini paylaşmaları sağlandı. }\end{array}$ \\
\hline 8 & $\begin{array}{l}\text { Saygı değerinin } \\
\text { işlenmesi }\end{array}$ & $\begin{array}{l}\text { Saygı değeri ile ilgili öğrencilerin ön bilgilerini ortaya çıkarmak için sorular } \\
\text { soruldu. } \\
\text { Saygı değeri ile ilgili bazı tanımlar ve bilgiler düz anlatım yöntemiyle anlatıldı. } \\
\text { Saygı değeri ile ilgili örnek olayların anlatıldı̆̆ı bazı videolar, fotoğraflar, kıssalar, } \\
\text { yaşanmış olaylar, hikâyeler ve saygı değeri ile özdeşleşmiş önemli şahsiyetler } \\
\text { ögrencilerle paylaşıldı. } \\
\text { Saygı değeri ile ilgili atasözleri, vecizeler, deyimler, şiirler, şarkılar gibi bazı } \\
\text { ürünler öğrencilerle paylaşıldı. } \\
\text { Öğrencilerin, saygı değeri ile ilgili yaşadıkları anılarını paylaşmaları için } \\
\text { konuşmalarına firsat verildi. }\end{array}$ \\
\hline
\end{tabular}




\begin{tabular}{|c|c|c|}
\hline & & $\begin{array}{l}\text { Beyin firtınası yöntemi kullanılarak saygının önemi, saygının sınırları, saygı } \\
\text { değerinin topluma ve bireye katkıları, saygı değerinin olmadığı durumlarda } \\
\text { nelerin yaşanabileceği } v b \text {. konularda ögrencilerin görüşlerini paylaşmaları } \\
\text { sağlandı. }\end{array}$ \\
\hline 9 & $\begin{array}{l}\text { Sevgi değerinin } \\
\text { işlenmesi }\end{array}$ & $\begin{array}{l}\text { Sevgi değeri ile ilgili öğrencilerin ön bilgilerini ortaya çıkarmak için sorular } \\
\text { soruldu. } \\
\text { Sevgi değeri ile ilgili bazı tanımlar ve bilgiler düz anlatım yöntemiyle anlatıldı. } \\
\text { Sevgi değeri ile ilgili örnek olayların anlatıldığı bazı videolar, fotoğraflar, kıssalar, } \\
\text { yaşanmış olaylar, hikâyeler ve dostluk değeri ile özdeşleşmişönemli şahsiyetler } \\
\text { ögrencilerle paylaşıldı. } \\
\text { Sevgi değeri ile ilgili atasözleri, vecizeler, deyimler, şiirler, şarkılar gibi bazı } \\
\text { ürünler öğrencilerle paylaşıldı. } \\
\text { Öğrencilerin, sevgi değeri ile ilgili yaşadıkları anılarını paylaşmaları için } \\
\text { konuşmalarına firsat verildi. } \\
\text { Beyin firtınası yöntemi kullanılarak sevginin önemi, sevginin sınırları, sevgi } \\
\text { değerinin topluma ve bireye katkıları, sevgi değerinin olmadığı durumlarda } \\
\text { nelerin yaşanabileceği vb. konularda öğrencilerin görüşlerini paylaşmaları } \\
\text { sağlandı. }\end{array}$ \\
\hline 10 & $\begin{array}{l}\text { Sorumluluk } \\
\text { değerinin } \\
\text { işlenmesi }\end{array}$ & $\begin{array}{l}\text { Sorumluluk değeri ile ilgili öğrencilerin ön bilgilerini ortaya çıkarmak için sorular } \\
\text { soruldu. } \\
\text { Sorumluluk değeri ile ilgili bazı tanımlar ve bilgiler düz anlatım yöntemiyle } \\
\text { anlatıldı. } \\
\text { Sorumluluk değeri ile ilgili örnek olayların anlatılldı̆ı bazı videolar, fotoğraflar, } \\
\text { kıssalar, yaşanmış olaylar, hikâyeler ve sorumluluk değeri ile özdeşleşmiş önemli } \\
\text { şahsiyetler öğrencilerle paylaşıldı. } \\
\text { Sorumluluk değeri ile ilgili atasözleri, vecizeler, deyimler, şiirler, şarkılar gibi bazı } \\
\text { ürünler öğrencilerle paylaşıldı. } \\
\text { Öğrencilerin, sorumluluk değeri ile ilgili yaşadıkları anılarını paylaşmaları için } \\
\text { konuşmalarına firsat verildi. } \\
\text { Beyin firtınası yöntemi kullanılarak sorumluluğun önemi, sorumluluğun sınırları, } \\
\text { sorumluluk değerinin topluma ve bireye katkıları, sorumluluk değerinin olmadı̆̆ı } \\
\text { durumlarda nelerin yaşanabileceği vb. konularda öğrencilerin görüşlerini } \\
\text { paylaşmaları sağlandı. }\end{array}$ \\
\hline 11 & $\begin{array}{l}\text { Vatanseverlik } \\
\text { değerinin } \\
\text { işlenmesi }\end{array}$ & $\begin{array}{l}\text { Vatanseverlik değeri ile ilgili öğrencilerin ön bilgilerini ortaya çıkarmak için } \\
\text { sorular soruldu. } \\
\text { Vatanseverlik değeri ile ilgili bazı tanımlar ve bilgiler düz anlatım yöntemiyle } \\
\text { anlatıldı. } \\
\text { Vatanseverlik değeri ile ilgili örnek olayların anlatılldığı bazı videolar, fotoğraflar, } \\
\text { kıssalar, yaşanmışs olaylar, hikâyeler ve dostluk değeri ile özdeşleşmiş önemli } \\
\text { şahsiyetler öğrencilerle paylaşıldı. } \\
\text { Vatanseverlik değeri ile ilgili atasözleri, vecizeler, deyimler, şiirler, şarkılar gibi } \\
\text { bazı ürünler öğrencilerle paylaşıldı. } \\
\text { Öğrencilerin, vatanseverlik değeri ile ilgili yaşadıkları anılarını paylaşmaları için } \\
\text { konuşmalarına firsat verildi. } \\
\text { Beyin firtınası yöntemi kullanılarak vatanseverliğin önemi, vatanseverliğin } \\
\text { sinırları, vatanseverlik değerinin topluma ve bireye katkıları, vatanseverlik } \\
\text { değerinin olmadığı durumlarda nelerin yaşanabileceği vb. konularda öğrencilerin } \\
\text { görüşlerini paylaşmaları sağlandı. }\end{array}$ \\
\hline
\end{tabular}


Examination of the impact of the course of character and value education on the attitudes of Turkish language and literature prospective teachers about value education / N. Şahin (p. 63-78)

\begin{tabular}{|c|c|c|}
\hline 12 & $\begin{array}{l}\text { Yardımseverlik } \\
\text { değerinin } \\
\text { işlenmesi }\end{array}$ & $\begin{array}{l}\text { Yardımseverlik değeri ile ilgili öğrencilerin ön bilgilerini ortaya çıkarmak için } \\
\text { sorular soruldu. } \\
\text { Yardımseverlik değeri ile ilgili bazı tanımlar ve bilgiler düz anlatım yöntemiyle } \\
\text { anlatıldı. } \\
\text { Yardımseverlik değeri ile ilgili örnek olayların anlatıldı̆̆ı bazı videolar, } \\
\text { fotoğraflar, ksısalar, yşanmışolaylar, hikâyeler ve dostluk değeri ile özdeşleşmiş } \\
\text { önemli şahsiyetler öğrencilerle paylaşıldı. } \\
\text { Yardımseverlik değeri ile ilgili atasözleri, vecizeler, deyimler, şiirler, şarkılar gibi } \\
\text { bazı ürünler öğrencilerle paylaşlldı. } \\
\text { Öğrencilerin, yardımseverlik değeri ile ilgili yaşadıkları anılarını paylaşmaları için } \\
\text { konuşmalarına firsat verildi. } \\
\text { Beyin firtınası yöntemi kullanılarak yardımseverliğin önemi, yardımseverliğin } \\
\text { sinırları, yardımseverlik değerinin topluma ve bireye katkıları, yardımseverlik } \\
\text { değerinin olmadığı durumlarda nelerin yaşanabileceği vb. konularda öğrencilerin } \\
\text { görusşlerini paylaşmaları sağlandı. }\end{array}$ \\
\hline 13 & $\begin{array}{l}\text { Genel bir } \\
\text { değerlendirme } \\
\text { yapılması }\end{array}$ & $\begin{array}{l}\text { Önceki haftalarda işlenmiş kök değerler ile ilgili kısa bir tekrar yapıldı. } \\
\text { Kök değerlerin birbirleriyle olan ilgileri hakkında beyin fırtınası yapıldı. }\end{array}$ \\
\hline 14 & $\begin{array}{c}\text { Değer Eğitimine } \\
\text { Yönelik Tutum } \\
\text { Ölçeği'nin son } \\
\text { test olarak } \\
\text { ögrencilere } \\
\text { uygulanması }\end{array}$ & $\begin{array}{l}\text { Ölçek öğrencilere dağıtıldı ve öğrenciler ölçeği okuyup doldurduktan sonra } \\
\text { toplandı. }\end{array}$ \\
\hline
\end{tabular}

\section{Verilerin analizi}

Araştırmanın tüm verileri SPSS 25 paket programı kullanılarak analiz edilmiştir. Araştırmada veriler analiz edilirken deneklerin ön test ve son test sonuçları arasındaki farkın anlamlı olup olmadığını test etmek için bağımlı örneklem t Testi kullanılmıştır.

\section{Bulgular}

\section{Araştırmadan elde edilen verilerin normallik testi sonuçları}

Öncelikle araştırmada elde edilen verilerin normal dağılım gösterip göstermedikleri SPSS 25 paket programında test edilmiştir. Bunun için verilerin çarpıklık ve basıklık değerlerine bakılmıştır. Elde edilen sonuçlar aşağıdaki tabloda gösterilmiştir. 
Tablo 3. Ön Test ve Son Test Verilerinin Çarpıklık ve Basıklık Değerleri

\begin{tabular}{|c|c|c|c|c|c|c|c|}
\hline & & 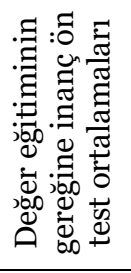 & 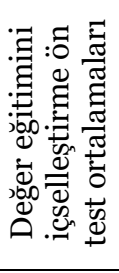 & 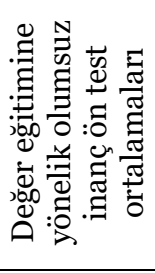 & 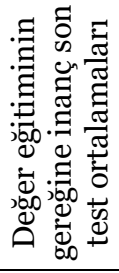 & 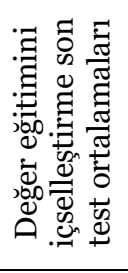 & 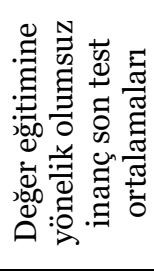 \\
\hline \multirow[t]{2}{*}{$\mathbf{N}$} & Valid & 50 & 50 & 50 & 50 & 50 & 50 \\
\hline & Missing & O & O & O & O & O & O \\
\hline \multicolumn{2}{|c|}{ Skewness } &,- 375 & ,053 & 1,868 & $-1,014$ &,- 211 & 1,040 \\
\hline \multicolumn{2}{|c|}{ Std. Error of Skewness } & ,337 & ,337 & ,337 & ,337 & ,337 & ,337 \\
\hline \multicolumn{2}{|c|}{ Kurtosis } &,- 443 &,- 322 & 1,123 &, 524 &,- 661 & 1,261 \\
\hline \multicolumn{2}{|c|}{ Std. Error of Kurtosis } & ,662 & ,662 & ,662 & ,662 & ,662 & ,662 \\
\hline
\end{tabular}

Tablo 3 incelendiğinde ön test ve son test verilerinin çarpıklık ve basıklık değerlerinin tamamının +2 ile -2 arasında olduğu görülmektedir.

George ve Mallery'e (2010) göre Skewness ve Kurtois değerlerinin +2 ile -2 değerlerinin arasında olması verilerin normal dağıldığını göstermektedir. Buna göre araştırmanın verileri normal dağılım göstermektedir.

Öte taraftan birçok bilim adamına göre (Çil, 2008; Aktürk ve Acemoğlu, 2011; Büyüköztürk vd., 2013; Armutlulu, 2008; Levine, Ramsey ve Smidt, 2001) 30'un üzerinde bir örnekleme sahip olan araştırmaların verilerinin normal dağılım gösterdiği kabul edilir. Bu araştırma ise, 50 katılımcı ile gerçekleştirildiği için araştırmanın verilerinin normal dağıldığı kabul edilmiştir. Bu sebeple de veriler analiz edilirken parametrik testlerden faydalanılmıştır.

\section{Araştırmanın birinci alt problemine ilişkin bulgular}

Bu bölümde; Karakter ve Değerler Eğitimi dersine ilişkin deneysel işlemlerden sonra, öğretmen adaylarının "Değer Eğitimine Yönelik Tutum Ölçeği”nin 1. faktörü olan "Değer Eğitiminin Gereğine Olan İnanç" alt boyutuna yönelik tutumları bağlamında almış oldukları ön test ve son test puanları arasında anlamlı bir fark olup olmadığını tespit etmek amaçlanmıştır. Bunun için, öğretmen adaylarının "Değer Eğitiminin Gereğine Olan İnanç" alt boyutunda almış oldukları ön test ve son test sonuçları bağımlı örneklem t- testi ile analiz edilmiştir. İlgili analizden elde edilen sonuçlar Tablo 4'te gösterilmiştir.

Tablo 4. Öğretmen Adaylarının “Değer Eğitiminin Gereğine Olan İnanç” Alt Boyutunda Almış Oldukları Ön Test ve Son Test Sonuçlarının Bağımlı Örneklem T- Testi Sonuçları

\begin{tabular}{ccccccc}
\hline & $\mathrm{N}$ & $\mathrm{X}$ & $\mathrm{SD}$ & $\mathrm{t}$ & $\mathrm{p}$ \\
\hline $\begin{array}{c}\text { Değer Eğitiminin } \\
\text { Gereğine Olan İnanç }\end{array}$ & Ön Test & 50 & 4,02 &, 517 & $-6,898$ & .000 \\
\cline { 2 - 5 } & Son Test & 50 & 4,58 &, 346 & &
\end{tabular}

Tablo 4 incelendiğinde "Değer Eğitiminin Gereğine Olan İnanç" alt boyutunda son test ortalama puanlarının ön test puanlarına göre anlamlı düzeyde farklılaştı̆̆ görülmektedir $\left(t_{49}=-6,898, p<.00\right)$. 
Examination of the impact of the course of character and value education on the attitudes of Turkish language and literature prospective teachers about value education / N. Şahin (p. 63-78)

Öğretmen adaylarının ön test aritmetik ortalamalarının $X=4,02$ ve son test aritmetik ortalamalarının $X=4,58$ olduğu görülmektedir. Buna göre uygulanan Karakter ve Değerler Eğitimi dersinin öğretmen adaylarının değer eğitiminin gereğine olan inanç tutumları üzerinde anlamlı bir etki oluşturduğu ve değer eğitiminin gerekliliğine olan inançlarını artırdığı söylenebilir.

\section{Araştırmanın ikinci alt problemine ilişkin bulgular}

Bu bölümde; Karakter ve Değerler Eğitimi dersine ilişkin deneysel işlemlerden sonra, öğretmen adaylarının "Değer Eğitimine Yönelik Tutum Ölçeği”nin 2. faktörü olan “Değer Eğitimini İçselleştirme” alt boyutuna yönelik tutumları bağlamında almış oldukları ön test ve son test puanları arasında anlamlı bir fark olup olmadığını tespit etmek amaçlanmıştır. Bunun için, öğretmen adaylarının "Değer Eğitimini İçselleştirme" alt boyutunda almış oldukları ön test ve son test sonuçları bağımlı örneklem t- testi ile analiz edilmiştir. İlgili analizden elde edilen sonuçlar Tablo 5’te gösterilmiştir.

Tablo 5. Öğretmen Adaylarının “Değer Eğitimini İçselleştirme” Alt Boyutunda Almış Oldukları Ön Test ve Son Test Sonuçlarının Bağımlı Örneklem T- Testi Sonuçları

\begin{tabular}{cllllll}
\hline & & $\mathrm{N}$ & $\mathrm{X}$ & $\mathrm{SD}$ & $\mathrm{t}$ & $\mathrm{p}$ \\
\hline $\begin{array}{c}\text { Değer Eŭitimini } \\
\text { İçselleştirme }\end{array}$ & Ön Test & 50 & 3,30 &, 802 & $-5,873$ & .000 \\
\cline { 2 - 5 } & Son Test & 50 & 4,10 &, 555 & & \\
\hline
\end{tabular}

Tablo 5 incelendiğinde "Değer Eğitimini İçselleştirme" alt boyutunda son test ortalama puanlarının ön test puanlarına göre anlamlı düzeyde farklılaştığı görülmektedir $\left(t_{49}=-5,873, p<.00\right)$. Öğretmen adaylarının ön test aritmetik ortalamalarının $X=3,30$ ve son test aritmetik ortalamalarının $X=4,10$ olduğu görülmektedir. Buna göre uygulanan Karakter ve Değerler Eğitimi dersinin öğretmen adaylarının değer eğitimini içselleştirme tutumları üzerinde anlamlı bir etki oluşturduğu ve değer eğitimini içselleştirme noktasındaki tutumlarını artırdığı söylenebilir.

\section{Araştırmanın üçüncü alt problemine ilişkin bulgular}

$\mathrm{Bu}$ bölümde; Karakter ve Değerler Eğitimi dersine ilişkin deneysel işlemlerden sonra, öğretmen adaylarının "Değer Eğitimine Yönelik Tutum Ölçeği”nin 3. faktörü olan "Değer Eğitimine Yönelik Olumsuz İnanç" alt boyutuna yönelik tutumları bağlamında almış oldukları ön test ve son test puanları arasında anlamlı bir fark olup olmadığını tespit etmek amaçlanmıştır. Bunun için, öğretmen adaylarının "Değer Eğitimine Yönelik Olumsuz İnanç" alt boyutunda almış oldukları ön test ve son test sonuçları bağımlı örneklem t- testi ile analiz edilmiştir. İlgili analizden elde edilen sonuçlar Tablo 6'da gösterilmiştir.

Tablo 6. Öğretmen Adaylarının “Değer Eğitimine Yönelik Olumsuz İnanç” Alt Boyutunda Almış Oldukları Ön Test ve Son Test Sonuçlarının Bağımlı Örneklem T- Testi Sonuçları

\begin{tabular}{cllllll}
\hline & & $\mathrm{N}$ & $\mathrm{X}$ & $\mathrm{SD}$ & $\mathrm{t}$ & $\mathrm{p}$ \\
\hline $\begin{array}{c}\text { Değer Eŭitimine Yönelik } \\
\text { Olumsuz İnanç }\end{array}$ & Ön Test & 50 & 1,47 &, 395 & \multirow{2}{*}{, 947} & .348 \\
\cline { 2 - 5 } & Son Test & 50 & 1,40 &, 394 & & \\
\hline
\end{tabular}


Tablo 6 incelendiğinde “Değer Eğitimine Yönelik Olumsuz İnanç” alt boyutunda son test ortalama puanlarının ön test puanlarına göre anlamlı düzeyde farklılaşmadığı görülmektedir $\left(\mathrm{t}_{49}=, 947 \mathrm{p}<.00\right)$. Öğretmen adaylarının ön test aritmetik ortalamalarının $X=1,47$ ve son test aritmetik ortalamalarının $\mathrm{X}=1,40$ olduğu görülmektedir. Buna göre araştırmaya katılan öğretmen adaylarının deneysel işlemlerden önce de değer eğitimine yönelik olumsuz inançlarının olmadığı, bu durumun deneysel işlemlerden sonrada devam ettiği söylenebilir. Yani uygulanan Karakter ve Değerler Eğitimi dersi, öğretmen adaylarında, değer eğitimine yönelik herhangi bir olumsuz inanç oluşturmamaktadır.

\section{Sonuç ve öneriler}

Karakter ve Değerler Eğitimi dersinin, Türk dili ve edebiyatı öğretmeni adaylarının değer eğitimine yönelik tutumları üzerindeki etkisini tespit etmeyi amaçlayan bu araştırmaya benzer deneysel çalışmalara literatürde rastlanılmamıştır. Araştırmadan elde edilen sonuçların karşılaştırılarak tartışma yapılabileceği başka çalışmalar olmadığından bu araştırmanın sonuçları, değer eğitiminin katılımcıların çeşitli becerileri üzerindeki etkilerini konu edinen ve bu çalışmanın sonuçlarına da işaret ettiği düşünülen araştırma sonuçları ile karşılaştırılmıştır. Bu bağlamda çalışmadan elde edilen sonuçlar aşağıda maddeler hâlinde dikkatlere sunulmuştur:

Araştırmanın birinci alt problemini “Karakter ve Değerler Eğitimi dersini alan öğretmen adaylarının, değer eğitiminin gereğine olan inanç bağlamında almış oldukları ön test ve son test puanları arasında anlamlı bir fark var mıdır?” sorusu oluşturmaktadır. Yapılan analizlere göre; Karakter ve Değerler Eğitimi dersi, öğretmen adaylarının değer eğitiminin gereğine olan inançları noktasındaki tutumlarını artırdığı sonucuna ulaşılmıştır. İlgili literatür incelendiğinde; araştırmanın bu sonucuyla örtüşen başka çalışmaları görmek mümkündür. Örneğin; Kozikoğlu (2018), okul öncesi öğretmenlerinin değerler eğitimine ilişkin tutumlarını ve okul öncesinde değerler eğitimine ilişkin görüşlerini araştırdığı çalışmasında, 110 okul öncesi öğretmeninden ölçek ve görüşme formu aracllığlyla veri toplamıştır. Kozikoğlu elde ettiği verilerin analizi neticesinde, okul öncesi öğretmenlerinin değer eğitimine yönelik yüksek düzeyde olumlu tutuma sahip oldukları sonucuna ulaşmıştır. Literatürde, değer eğitimine yönelik tutumların araştırıldığı bir başka çalışma da ise, Yaşaroğlu (2014); sınıf öğretmenlerinin okullarda uygulanmakta olan değerler eğitimine ilişkin tutumlarını belirlemeyi amaçlamıştır. Değerler eğitimine yönelik tutumu olumlu olan öğretmenlerin değerler eğitimini daha etkin olarak uygulayacağını vurgulayan araştırmacı, çalışmasında 25 maddeden oluşan "Değerler Eğitimi Tutum Ölçeği” geliştirmiş ve uygulamıştır. Toplamda 158 öğretmenden elde edilen verilerin analizinde araştırmacı; sınıf öğretmenlerinin değerler eğitimine yönelik tutumlarının olumlu olduğu sonucuna ulaşmıştır. Tamuri (2007) ise, Malezya'da gerçekleştirdiği çalışmasında öğretmenlerin ahlak eğitimi ile ilgili görüsslerini araştırmıştır. Tamuri, çalışmasının sonunda, öğretmenlerin ahlak eğitiminden memnun olduklarını ifade etmiştir.

Araştırmanın ikinci alt problemini "Karakter ve Değerler Eğitimi dersini alan öğretmen adaylarının, değer eğitimini içselleştirme bağlamında almış oldukları ön test ve son test puanları arasında anlamlı bir fark var mıdır?" sorusu oluşturmaktadır. Yapılan analizler neticesinde, Karakter ve Değerler Eğitimi dersinin, öğretmen adaylarının değer eğitimini içselleştirme noktasındaki tutumlarını artırdığı görülmüştür. Literatürde, araştırmanın bu sonucuyla örtüşen başka çalışmalar da vardır. Örneğin: Demirhan Iscan ve Senemoğlu'nu (2009), ilköğretim 4. sinıf düzeyinde "evrensellik" ve "iyilikseverlik" değerlerini kazandırmaya yönelik hazırladıkları değerler eğitimi programının; öğrencilerin değerlerle ilgili bilişsel davranışlarına, duyuşsal özelliklerine ve değerleri gösterme düzeylerine etkisini araştırdıkları çalışmalarında, ön test son test kontrol gruplu deneysel desen kullanmışlardır. 
Examination of the impact of the course of character and value education on the attitudes of Turkish language and literature prospective teachers about value education / N. Şahin (p. 63-78)

Araştırmacılar, çalışma sonucunda; deney grubundaki öğrencilerin değerlere ilişkin bilişsel davranışları kazanma düzeyleri, kontrol grubu öğrencilerinden anlamlı bir biçimde yüksek bulunduğunu ve deney grubundaki öğrencilerin, gerçekleştirilen görüşmelerde, kontrol grubu öğrencilerine göre değerlerin özelliklerini yansıtan daha fazla ifade kullandıklarını ifade etmişlerdir. Programa katılmayan öğrencilerin, programa katılan öğrencilere göre, daha fazla değerlerin özelliklerinin aksini yansıtan ifadeler kullandıklarını vurgulayan Demirhan Iscan ve Senemoğlu’nun ulaştığı sonuçlardan bir başkası da; deney grubu öğrencilerinin, kontrol grubu öğrencilerine göre, programın uygulanması sırasında değerlere ilişkin daha çok olumlu nitelikte davranış sergiledikleridir. Değer eğitiminin değerleri içselleştirme süreci üzerindeki olumlu etkisinin konu edinildiği bir başka çalışmada ise, Aladağ (2012); ilköğretim 5. sınıf Sosyal Bilgiler dersinde uygulanacak olan değer öğretim programının öğrencilerin "sorumluluk" değerini bilişsel düzeyde kazanmalarına etkisini belirlemeyi amaçlamıştır. Ön test son test kontrol gruplu deneysel desende gerçekleştirilen çalışmanın uygulamaları 8 hafta sürmüştür. Araştırmadan elde edilen sonuçlar; deney grubu ve kontrol grubu öğrencilerin uygulama sonrası "sorumluluk" değerine ilişkin, Bilişsel Düzey Ölçeğinden elde etmiş oldukları puanlar arasında deney grubu lehine anlamlı fark bulunduğunu göstermektedir.

Araştırmanın üçüncü alt problemini “Karakter ve Değerler Eğitimi dersini alan öğretmen adaylarının, değer eğitimine yönelik olumsuz inanç bağlamında almış oldukları ön test ve son test puanları arasında anlamlı bir fark var mıdır?” sorusu oluşturmaktadır. Yapılan analizler neticesinde öğretmen adaylarının, değer eğitimine yönelik olumsuz inanç alt boyutunda almış oldukları ön test ve son test puanları arasındaki anlamlı değildir. Elde edilen veriler, araştırmaya katılan çalışma grubunun deneysel işlemler öncesinde de değer eğitimine yönelik olumsuz bir inanca sahip olmadıklarını, deneysel işlemler sonrasında da öğretmen adaylarında değer eğitimine yönelik herhangi bir olumsuz inanç gelişmediğini göstermektedir. Değer eğitimine yönelik olumsuz tutumların konu edinildiği bir başka çalışma olan Yaşaroğlu'nun (2014) çalışmasında ise, araştırmanın bu sonucunun aksine öğretmen adaylarının değer eğitimine yönelik para harcanmaması inancında oldukları sonucuna ulaşılmıştır. Yaşaroğlu, bu sonucun tutum-davranış tutarsızlığı bağlamında incelenmesi gerektiğini ifade etmiştir.

Araştırma sonucunda elde edilen verilerden hareketle aşă̆ıda sıralanan önerilere yer verilmiştir:

Bu araştırmada veri toplama aracı olarak ölçek kullanılmıştır. Ölçek, elde edilen verilerin kapsamını ve geçerliğini sınırlamaktadır. Bu nedenle Karakter ve Değerler Eğitimi dersinin etkinliğine yönelik daha zengin ve derinlemesine veriler elde edebilmek için ölçek ve anketlerin yanında görüşme ve gözlem yöntemlerinin kullanılarak verilerin toplandığı araştırmalar yapılmalıdır. Nitel veri toplama araçları ile gerçekleştirilecek çalışmalardan elde edilen sonuçlarla, bu çalışma gibi nicel çalışmalardan elde edilmiş sonuçların karşılaştırılması; fotoğrafa bütün olarak bakılması bağlamında önem arz etmektedir.

Karakter ve Değerler Eğitimi dersinin öğretmen adayları dışındaki farklı örneklem grupları (öğretmenler, eğitim yöneticileri, öğrenciler $v b$.) üzerindeki etkisi üzerine nitel ve nicel araştırmalar yapılmalıdır.

Karakter ve Değerler Eğitimi dersinin sosyal, bilişsel ve davranışsal alanlardaki farklı beceriler üzerindeki etkisini araştıran nitel ve nicel araştırmalar yapılmalıdır.

Karakter ve değer eğitimine yönelik dersler yüksek öğretimde birçok fakülte ve bölümde hiç yer almamakta, bazı fakültelerin birkaç bölümünde ise seçmeli ders olarak yer almaktadır. Milletimizin ve devletimizin istisnasız her alanda karakterli ve değerlerine sahip çıkan insanlara olan ihtiyacı göz önüne 
alındığında, Karakter ve Değerler Eğitimi dersinin özellikle yükseköğretimde zorunlu hâle getirilmesi ve bu derse yönelik etkili öğretim programlarının ve ders içeriklerinin hazırlanması gerekmektedir. Özellikle günümüz genç neslindeki ahlâki çöküntüler ve kişilik bozuklulukları; karakter ve değer eğitimine en çok ihtiyaç duyulan eğitim kademesinin yükseköğretim olduğu mesajını vermektedir.

\section{Kaynakça}

Aktürk, Z. ve Acemoğlu, H. (2011). Sağllk çalışanları için araştırma ve pratik istatistik. İstanbul: Anadolu Ofset.

Akyüz, H. (1991). Eğitim sosyolojisinin temel kavram ve alanları üzerine bir araştırma. İstanbul: Millî Eğitim Bakanlığı Yayınları.

Aladağ, S. (2012). İlköğretim sosyal bilgiler öğretiminde değer eğitimi yaklaşımlarının öğrencilerin sorumluluk değerini bilişsel düzeyde kazanmalarına etkisi. Türkiye Sosyal Araştırmalar Dergisi, $16(1), 123-146$.

Alyılmaz, C. ve Alyılmaz, S. (2014). Amirbek Turatoviç Muratov'dan Yenisey'e sesleniş. Uluslararası Türkçe Edebiyat Kültür Eğitim Dergisi. 3/1, 68-84.

Alyılmaz, S. (2008). Öğretmen adaylarına göre görgü kurallarına aykırı davranışlar. İzvestiya Vuzov, 1$2,136-142$.

Armutlulu, İ. H. (2008). İşletmelerde uygulamalı istatistik. İstanbul: Alfa Yayıncılık.

Bayram, B. ve Yılmaz, S. (2019). Değer eğitiminde edebî türlerin kullanımı. Salih Zeki Genç ve Adem Beldağ (Ed.), Karakter ve Değer Eğitimi (279-292) içinde. Ankara: Pegem Akademi.

Beil, B. (2003). İyi çocuk, zor çocuk, 'doğru davranışlar çocuklara nasıl kazandırılır? (Çev. Cuma Yorulmaz). Ankara: Arkadaş Kitapevi.

Bilgin, N. (1995). Sosyal psikolojide yöntem ve pratik çalışmalar. İstanbul: Sistem Yayıncılık.

Büyüköztürk, Ş (2007). Deneysel Desenler, Öntest-Sontest Kontrol Grubu Desen ve Veri Analizi. Ankara: PegemA Yayıncilık .

Büyüköztürk, Ş.; Çokluk, Ö. ve Köklü, N. (2013). Sosyal bilimler için istatistik. Ankara: Pegema Yayıncllı.

Cohen, L. ve Manion, L. (1997). Reseacrh methods in education (4th ed.). Routledge: London and New York.

Çetin, F. (2018). Değer eğitimine yönelik tutum ölçeği. Türkiye Sosyal Araştırmalar Dergisi, 22 (193), 323-341.

Çil, B. (2008). İstatistik. Ankara: Detay Yayıncllı.

Demirhan Iscan, C. ve Senemoğlu, N. (2009). İlköğretim 4. sınıf düzeyinde değerler eğitimi programının etkililiği. Ĕgitim ve Bilim, 34 (153), 1-14.

Doğan, H. (1997). Eğitimde program ve öğretim tasarımı. Ankara: Önder Matbaacılık.

Dökmen, Ü. (2000). İletişim çatışmaları ve empati. İstanbul: Sistem Yayıncılık.

Er, O. (2017). Suha Mermerci'nin Kitaplarının Kültürel Değerler Açısından Değerlendirilmesi. Uluslararası Türkçe Edebiyat Kültür Eğitim Dergisi, 6(2), 1178-1188.

Erdentuğ, N. (1982). Kişiliğin oluşması ve Türk kimliği. D.T.C.F. Atatürk’ün 100. Doğum Yılına Armağan Dergisi, 323. Ankara: Ankara Üniversitesi.

Fraenkel, J. R., ve Wallen, N. E. (1996). How to design and evaluate research in education (3th ed.). Mc Graw Hill Higher Education. New York, ABD.

Gay, L. R., ve Airasian, P. (2000). Educational research competencies for analysis and application (6th Edition). Ohio: Merrill an imprint of Prentice Hall. 
Examination of the impact of the course of character and value education on the attitudes of Turkish language and literature prospective teachers about value education / N. Şahin (p. 63-78)

George, D., ve Mallery, M. (2010). SPSS for Windows Step by Step: A Simple Guide and Reference, 17.0 update (10a ed.) Boston: Pearson.

Halstead, J. M. ve Taylor, M. J. (2000). Learning and teaching about values: a review of recent research. Cambridge Journal Of Eucation, 30(2), 169 - 202.

Kale, N. (2004). Nasıl bir değerler eğitimi? Değerler ve Eğitimi Uluslararası Sempozyumu'nda sunulan bildiri, İstanbul.

Karasar, N. (2003). Bilimsel Araştırma Yöntemi. (12. Baskı). Ankara: Nobel Yayıncılık

Kavcar, C. (1999). Edebiyat ve eğitim. (3. Basım). Ankara: Engin Yayıncılık.

Kozikoğlu, İ. (2018). Okul öncesi öğretmenlerinin değerler eğitimine ilişkin tutum ve görüşlerinin incelenmesi. Uluslararası Türkçe Edebiyat Kültür Eğitim Dergisi, 7(4), 2698-2720.

Köktürk, M. (2006). Kültürün dünyası, kültür felsefesine giriş. Ankara: Hece Yayıncılık.

Levine, D. M.; Ramsey, P. P. ve Smidt, R. K. (2001). Applied statistics for engineers and scientists. Prentice Hall.

Nachmias, D. ve Nachmias, C. (1997). Research Methods in theSocial Sciences (2th ed.), New York: St. Martin's Pres.

Özgüven, İ. E (1994). Psikolojik testler. Ankara.

Şahin, N. (2017). Cengiz Aytmatov'un eserlerinin değerler eğitimi bağlamında incelenmesi ve ortaokul Türkçe ders kitapları için metin önerileri. Yayınlanmamış Doktora Tezi, Atatürk Üniversitesi Eğitim Bilimleri Enstitüsü, Erzurum.

Tamuri, A. H. (2007). Islamic Education teachers' perceptions of the teaching of akhlāq in Malaysian secondary schools. Journal of Moral Education, 36(3), 371- 386.

TDK, (2015). Türkçe sözlük. Ankara: TDK Yay.

Yaşaroğlu, C. (2014). Sınıf öğretmenlerinin değer eğitimine yönelik tutumlarının çeşitli değişkenler açısından incelenmesi. JASSS, 27, 123-134. 